\title{
Innovation and Practice of Graduation Design Link of Engineering Specialty Based on Employment Demand
}

\author{
YingHui Liu ${ }^{1}$,XiaoDan Zhang ${ }^{{ }^{*}}{ }$ ZhenFang Song $^{2}$ \\ ${ }^{1}$ College of Electrical \& Information Engineering,Beihua University \\ ${ }^{2}$ Beihua University, College of physical education, Longteng innovation and entrepreneurship education base \\ *Corresponding author
}

Keywords: Employment position, Graduation project, Innovation and Practice.

\begin{abstract}
Based on the analysis of the actual to participate in the graduation design students after school-enterprise cooperation, the introduction of the mechanism of school-enterprise cooperation in local universities and engineering graduation design, graduation design consistent with the content of employment demand is a good innovation and practice. The reasonable arrangement of school-enterprise cooperation in graduation design can not only ensure the quality of graduation design, but also promote students' innovative and practical ability, so that students can quickly adapt to the future job demand.
\end{abstract}

Graduation project is an important practical teaching link for training creative talents in Colleges and universities, and it is also a routine subject in College teaching. At present, the guiding ideology of graduation project must vigorously promote the cultivation of College Students' innovative spirit and practical ability, and overcome the drawbacks of the traditional theory of Engineering Education from theory to practice. The local comprehensive university should combine its own regional position, and actively explore a way of innovation and practice of graduate design.

\section{The background of the innovation and practice of graduation project}

In order to speed up the innovation ability, to cultivate a large number of engineering and technical personnel to adapt to the needs of economic and social development, promote the transformation of China's engineering education from country to engineering education, the Ministry of Education held a "excellent engineer education and training program will start in Tianjin on June 23, 2010, with the relevant departments and Industry Association (Science) will jointly implement the" excellent engineer education and training plan "(hereinafter referred to as the" excellence "). The excellent plan adopts the joint training mode of universities and enterprises, pays great attention to train students' engineering practice ability and innovation ability, and requires that during the four years of undergraduate study, the study and work time of enterprises should be accumulated for 1 years. The start of the excellent project undoubtedly points out the direction for the innovation and practice of the graduation design of the local comprehensive university, that is, the graduation design of college students can try to take a road of innovation of school enterprise cooperation.

School enterprise cooperation graduation design and integration of schools and enterprises to make full use of educational resources, make the students complete theoretical guidance in the process of graduation design not only can get the school tutor, production practice and can be combined with their own employment direction to carry out the combination of theory and practice. The school enterprise combination of the graduation project fully responds to the spirit of the national Ministry of education's excellent plan initiative, and also conforms to the wishes of the 
school, the students and the three party of the enterprise. To cultivate talents for the society, improve the quality of teaching, to cultivate more talents to meet the social needs of the school development goals; students are hoping to get plenty of exercise in the graduation design, to participate in the actual production work to realize the transfer of knowledge to the theory of social wealth; and enterprises are welcome into the practical ability, skilled talents the role of fast, high quality occupation. School enterprise cooperation can not only guarantee the quality of graduation design, but also combine theory with practice well, and train excellent talents with high quality and strong ability.

Beihua University adhere to the talent cultivation as the fundamental task, establish "a main training goal of diversity, innovation and Practice on the" talent, thoroughly implement the spirit of the national education work conference and education plan, promote the construction and development of higher education, and strive to improve the quality of scientific and technological innovation ability and talent training. In the graduation project of college students, the school enterprise cooperation has also been actively explored and implemented. Through careful study and learn from the national Ministry of education excellence spirit connotation, the author explores actively take the way of school enterprise cooperation in graduation design for students, and school enterprise cooperation for graduation in electrical engineering, automation or other engineering professional in the design process to carry out research and practice analysis.

\section{Innovation and practice of graduation design link of Engineering Specialty}

The main contents of this research are: the analysis of how to implement the cooperation in the process of graduation design, how to ensure the school and enterprise cooperation to improve the guidance to the students, what is the role of the cooperation of graduation design, there may be cooperation problems and countermeasures. The subjects of the survey are ten senior students in communication engineering, electrical engineering, automation and automation in Beihua University. This article will combine the four aspects of graduation project selection, research methods, enterprise practice and graduation design output.

Graduation project topics selected. An important objective of the implementation of the cooperation between schools and enterprises in the process of graduation design is to improve college students' comprehensive use of the basic theory, professional knowledge and basic skills, ability to find, analyze and solve practical problems associated with the professional, and responsible for special technical work for the future to engage in scientific research work or participate in engineering design work under certain foundation, the college graduates can quickly adapt to the needs of the future work. Therefore, in the preparation of graduation project, we should give full consideration to the direction of employment of students, as close as possible to students after graduation work. In this way, students can complete the graduation project at the same time, after graduation work content to have a certain understanding and grasp.

In this research, a total of ten because of the original work is not associated with the graduation project after graduation, to improve the application ability to students is not significant students as the research object, the survey have been contracted, the employment unit also hope students graduation design combined with the actual business, to enable students to gain more professional skills after graduation can quickly adapt to the needs of jobs. With the employment unit repeatedly coordination deliberation, and ultimately determine the graduation design take the cooperation scheme, the graduation design at the school at the same time topics of graduation design can also go deep into the employment of specific business work, graduation design is more practical significance and practical value.

Graduation project research program. There is a need to properly solve the problem in the cooperation of graduation design, that is how to make full use of and integration of school and enterprise education resources, to ensure that students can get the guidance and sufficient practice to improve graduation design in. Only by solving this problem, can school enterprise cooperation play a proper role in innovation and practice in college graduate design. In the graduation project of school enterprise cooperation, both the theoretical guidance and the process supervision of school 
teachers are needed, and the practical guidance and real-time supervision of the cooperative units are required. The two are indispensable. However, students will inevitably from school in the enterprise, the inconvenience to the theoretical guidance and supervision; and the enterprise is not a unit of education, training and education of the school can not be like that focus on students. In view of the above problems, students are required to leave the school before the three parties together to determine reasonable graduate design research programs, and the use of the Internet and other communication tools at any time for information feedback and guidance.

Enterprise practice link. Refers to the students to make full use of the existing equipment of the enterprise environment students in enterprise production practice, combined with the work content of their jobs, practice and exploration in the graduation project selected, complete the "theory to guide practice, practice in the process of deepening understanding of the theory". Through the practice of enterprises, students can better connect theory with practice, which not only deepens the understanding and mastery of theoretical knowledge, but also improves students' practical ability and professional skills.

Graduation project achievement output. When students carry out production practice in the enterprise to meet the predetermined requirements, students need to return to school in time to complete the graduation project output. The output of graduation project mainly includes: drawing of related drawings, graduation design, thesis writing, graduation design, printing and binding of papers, and preparation for graduation defense. Graduation project achievement is the direct index to check the quality of graduation project. In the completion of graduation project output, the school teachers in accordance with the relevant school graduate design requirements for students to guide and supervise, to ensure that students on time and quantity to submit graduation project results.

At the graduation design, students return to school in early May and promptly report to the teacher internship and graduation design is completed, the preliminary results given by the teacher evaluation, and puts forward suggestions on the arrangement and follow-up work. Under the guidance of the teacher, it was born in mid May to complete the graduation thesis, the first draft of the paper, submitted to the teacher for approval. After reviewing the first draft of the graduation project, the teacher put forward the existing problems and gave some suggestions for revision. Finally, students revise their papers at the end of May, submitted to the printing and binding of good design graduate thesis, in early June to complete the graduation reply. The content of the reply is appropriate, the project is practical and the effect is good.

\section{Conclusion}

The graduation design is the cultivation of innovative talents in colleges is an important part of the practical teaching, in the process of graduation design in the introduction of the mechanism of school enterprise cooperation helps to cultivate outstanding college graduates with innovative and practical spirit. Through the investigation and analysis of design innovation and practice of the typical case of graduation material forming and control engineering after the introduction of the mechanism of school enterprise cooperation can be seen in the graduation design, reasonable arrangements for the graduation design in the process, carry out research according to the reality of employment and employment, which can guarantee the quality. Complete the graduation design at the same time, also for the graduates to participate in the specific work to lay a certain foundation, so that college graduates can quickly adapt to the needs of the job in the future.

\section{Acknowledgements}

This paper is a study on the status and Countermeasures of graduation project design and employment demand in engineering specialty - part of the research results in Longtan District of Jilin city.

\section{References}


[1] Zengxi. History of graduation design reform and practice [J]. Journal of Beijing University of Posts and Telecommunications (SOCIAL SCIENCE EDITION), 2002,7 (3): 49-52.

[2] Zhao Hanqiang, Guo Baolong. Enlightenment of cooperative education in foreign universities on the implementation of training program for excellent engineers in China [J]. higher education of science, 2011, (4): 49-52.

[3] Feng Jianjun, the "golden fire". Exploration and practice of "Trinity" contract personnel training mode in Higher Vocational Colleges [J]. higher education exploration, 2010, (5): 107-110.

[4] high Chi, Li Weixing. Research and exploration of empirical research on [J]. laboratory design group guidance mode of graduate 2011 (10).

[5] Wang Yan. Undergraduate graduation thesis (Design) the whole process of quality management evaluation system of [J]. knowledge economy 2011 (16).

[6] clock. Improve the quality of undergraduate graduation design Li Fei's thinking [J]. computer knowledge and technology the whole process of quality management. 2010 (02)

[7] Cheng Weimin, Liu Yin. Undergraduate graduation design (Thesis) quality process control [J]. Chinese power education. 2009 (11)

[8] Peng Xiwei, Liao Xiaozhong, Peng Guangzheng. Undergraduate graduation design teaching exploration and practice of [J]. education. China power 2009 (06)

[9] Su Ping, Guo Hongcheng. On improving the quality of graduation design in Colleges of Engineering [J]. China thinking power education 2009 (04). 